\title{
Bir çocuk yanık merkezinde hastaların kültürlerinde üreyen mikroorganizmalar ve mortaliteye etkileri
}

\section{The microorganisms isolated from patients' cultures in a cild burn center and its impact to mortality}

\section{Sabri DEMIR ${ }^{1 a}$, Emrah ŞENEL ${ }^{2}$}

1 Bartın Devlet Hastanesi Çocuk Cerrahisi Kliniği, Bartın,

${ }^{2}$ Ankara Çocuk Sağlığı ve Hastalıkları Hematoloji Onkoloji Eğitim ve Araştırma Hastanesi Çocuk Cerrahisi Kliniği, Ankara, TÜRKiYE

\section{öz}

Amaç: Günümüzde, yanık hastaları en çok yanığı takiben gelişen enfeksiyonlar nedeni ile kaybedilmektedir. Bu çalışmanın amacı çocuk yanık merkezimizde yatarak tedavi gören hastalarda görülen enfeksiyon etkenlerini ve mortaliteye etkilerini ortaya koymaktır.

Gereç ve Yöntemler: Çalışmamızda, çocuk yanık yoğun merkezimizde Ocak 2009 ve Ağustos 2013 tarihleri arasında yatarak tedavi gören 503 çocuk yanık hastasının dosyaları ve bilgisayar kayıtları retrospektif olarak incelendi. Hastaların yaşı, cinsiyeti, yanık alanı, yanık nedeni, yanık yüzdesi, yattığı gün sayısı, enfeksiyon geçirip geçirmediği, kan testleri, yara sürüntüsü, idrar ve kateter kültürleri, antibiyotik ve/veya antifungal tedavi alıp almadığı verileri incelendi.

Bulgular: Mortalite oranımız \%2,2 ( $\mathrm{n=11)}$ olarak bulundu. Hastaların en sık görülen ölüm nedeni $(\% 54.5, \mathrm{n}=6)$ enfeksiyonlar idi. Kaybedilen altı hastanın yara kültürlerinde en sık üreyen mikroorganizma Acinetobacter baumannii (\%28,6), kan kültürlerinde en sık üreyen mikroorganizma Psödomonas aureginosa $(\% 21,4)$, kateter kültürlerinde ise Acinetobacterbaumannii, Candida türleri, Enterococcus türleri ve Streptococcus türleri eşit oranda üredi.

Sonuçlar: Yanık hastaları hastane ortamında yüksek morbidite ve mortaliteye sahip kritik hasta grubunu oluştururlar. Çocuk yanık hastalarında enfeksiyonlar, morbidite ve mortalitenin en sık nedeni olmaya devam etmektedirler.

Anahtar Kelimeler: Çocuklar, yanık, kültür, enfeksiyon, sepsis, mortalite. 


\section{ABSTRACT}

Aim: Contemporarily, burn patients are lost mostly due to emerging infections following burns. The aim of this study is to reveal causative agents of infections and their effects on mortality in hospitalized burn patients in our children burn center.

Material and method: In our study, the files and computer records of the 503 children who were hospitalized in our children burn center between January 2009 and August 2013 were evaluated retrospectively. Patients' characteristics including age, sex, cause of burn, percentage of burn, the number of hospitalization days, whether or not an infection occured, blood tests, wound swabs, urine and catheter cultures,whether or not antibiotics and / or antifungal therapy was received were evaluated, retrospectively.

Results: Our mortality rate was found $2.2 \%(n=11)$. The most frequent cause of death was found as infections $(54.5 \% ; n=6)$. In wound cultures of six patients who died due to infections, the most isolated bacteria was Acinetobacter baumannii (28.6\%), in blood cultures the most isolated bacteria was Pseudomonas aureginosa (21.4\%), and in catheter cultures Acinetobacter baumannii, Candida spp., Enterococcus spp. and Streptococcus spp. were isolated in equal proportions.

Conclusion: Burn patients form the group with high morbidity and mortality in critically ill patients in the hospital setting. Infections in pediatric burn patients continue to be the most common cause of morbidity and mortality.

Key words: Children, burn, culture, infection, sepsis, mortality.

\section{Giriş}

Yanık; organizmanın sıcak, yanıcı veya yakıı bir ajan ile temas etmesi sonucu oluşan doku hasarına denir. Son 30 yıldır yanık tedavisinde sağlanan gelişmelerin sonucunda ölüm oranlarında belirgin oranda düşüş sağlandı. Bundan 25 yıl önce vücut yüzeyinin \%50'si yanmış olan genç yetişkinlerde mortalite tedaviye rağmen $\% 50$ civarında iken, günümüzde benzer hastalarda mortalite $\% 10^{\prime}$ un altına inmiştir. Sağ kalım oranlarındaki bu iyileşmenin nedenleri, erken dönemdeki resusitasyon, cerrahi teknikler, enfeksiyonun kontrolü ve nutrisyonel / metabolik destek alanlarındaki ilerlemeler olarak sıralanabilir [1]. Günümüzde yanık hastaları, daha çok akut dönemdeki hipovolemik şok nedeni ile değil, yanığı takiben gelişen enfeksiyonlar nedeni ile kaybedilmektedir [2].

Yanığın erken dönemlerde daha çok vücudun sağlam deri bölgesinde olan gram pozitif bakterilerin kolonize oldukları ve uygun bakım yapılmayan yanık dokusunda enfeksiyon gelişiminden sorumlu oldukları bildirilmektedir. Bu patojenler içinde Staphylococcus aureus, Staphylococcus epidermidis ve diğer stafilokok türleri, Streptococcus pyogenes ve diğer streptokok türleri, Enterococcus türleri, Corynebacterium türleri, difteroid basiller, mikrokoklar ve Candida albicans gibi mantar türleri bulunmaktadır. Gram pozitif mikroorganizmalar ve Candida albicans için bulaşta rol oynayan bir başka kaynak ise gastrointestinal sistemdir. Burada Staphylococcus aureus, Staphylococcusepidermidis, diğerstafilokoktürleri,Streptococcus pyogenes ve bazen de Enterococcus türleri patojen olarak bulunur ve yanık infeksiyonları için kaynak rolü oynayabilirler. Bunların dışında yanık enfeksiyonlarına neden olabilen gram pozitif koklar Peptococcus türleri, Peptostreptococcus türleri gibi anaerob ajanlar, gram pozitif basiller Listeria monocytogenes, Bacillus türleri ve Clostridium türleridir [3].

Bu çalışmanın amacı: çocuk yanık merkezimizde yatarak tedavi gören hastalarda görülen enfeksiyon etkenlerini ve mortaliteye etkilerini ortaya koymaktır.

\section{Gereç ve Yöntemler}

Çalışmamızda, Ankara Çocuk Sağlığı ve Hastalıkları Hematoloji Onkoloji Eğitim ve Araştırma Hastanesi Yanık Merkezinde Ocak 2009 ve Ağustos 2013 tarihleri arasında yatarak tedavi gören 503 çocuk yanık hastasının dosyaları ve bilgisayar kayıtları retrospektif olarak değerlendirildi.

Yatış esnasında hastaların; yaş, cinsiyet, toplam vücut yüzey alanı (TVYA), diyagram üzerinden toplam vücut yanık alanı, yanık nedeni, yanık yüzdesi, yanık dışında ek patolojileri olup olmadığı kaydedildi. Dosya ve bilgisayar kayıtlarının taranmasında bu bilgilerin yanı sıra hastaların yattığı gün sayısı, enfeksiyon geçirip geçirmediği, çalışılan kan, yara sürüntüsü, idrar ve kateter kültürleri, antibiyotik ve/veya antifungal tedavi alıp almadığı verileri incelendi. Ayrıca hastaların kültürlerinde üreme olduysa üreyen mikroorganizma türünün mortalite ile ilişkili olup olmadığı ve hastaların ölüm nedenleri kayıt edildi. Başka bir merkezde hastaneye yatırılıp tedavileri başlandıktan sonra sevkedilen hastalar geldiklerinde izole odaya alınıp yara, kan, idrar ve boğaz kültürleri alındı. Sonuçlarına gore tedavileri düzenlendi. Direkt merkezimize yatan hastalardan ise geldikleri gün kültür alınmadı. Sonraki günlerde gerekli görüldüğünde kültürlerine bakıldı.

İstatistiksel analizler ve hesaplamalar için IBM SPSS Statistics 21.0 (IBM Corp. Released 2012. IBM SPSS Statistics for Windows, Version21.0. Armonk, NY: IBM Corp.) ve MS-Excel 2007 programları kullanıldı. İstatistiksel anlamlılık düzeyi $p<$ 0.05 olarak kabul edildi.

\section{Bulgular}

Yanık ünitemize Ocak 2009 ve Ağustos 2013 tarihleri arasında toplam 503 hasta yatırıldı. Bu hastaların \%61,6 ( $n=310)$ 'sı erkek, \%38,4 ( $n=193)^{\prime}$ ü kızdı ve yaşları 1 ay ile 17 yaş arasında (ortanca yaş 2 yıl) değişmekteydi. Hastalarımızda en sık sıcak sıvılar ile (su, süt, konsantre sıvılar) haşlanma yanığı görüldü $(\% 78,3 ; n=394)$. Bunu sırası ile alev (\%17,3; $n=879)$, elektrik $(\% 3 ; n=15)$, sıcak cisimlere (soba, ütü) temas $(\% 0,8 ; n=4)$ ve kimyasal yanıklar $(\% 0,6 ; n=3)$ takip etti. 
Hastaların \%21,7 ( $n=109)$ 'si hastanemize direk başvururken, \%78,3 ( $n=394$ )'i başka bir sağlık biriminden sevkli geldi. Yanık merkezimize yatırılan hastaların \%97,8 ( $n=492)$ 'i taburcu edilirken \%2,2 ( $n=11)$ 'si kaybedildi.

Hastaların \%41,9 ( $\mathrm{n}=211$ )'undan yara, kan, kateter ve / veya idrar kültürü bakılırken diğer hastalardan hiçbir kültür bakılmadı. Kültür istenen 211 hastanın \%52,6 (n=111)'sının kültürlerinde üreme görülürken diğerlerinde üreme tespit edilmedi.

Hastaların \%31,2 ( $n=157)$ 'sinden toplam 491 yara kültürü çalışıldı. Kültür istenen hastaların \%61,1 ( $n=96)$ 'inin yara kültürlerinde üreme oldu. Hastalardan istenen yara kültür sayıları baz alındığında en sık Acinetobacter baumannii üredi. Bunun ardından da Staphylococcus türleri, Pseudomonas aureginosa ve Candida türleri en sık üreyen mikroorganizmalar oldu (Tablo 1 ve 2).
Hastaların bir kısmında aynı pansuman sırasında çok sayıda yara kültürü alınması nedeni ile aynı mikroorganizma, aynı seansta alınan kültür sayısınca üredi. Bu yüzden toplam yara kültürleri baz alınarak yapılan istatistikte yanılmalar olabileceği düşünülerek, aynı hastada ve aynı seansta birden fazla üreyenlerin sayısı bire düşürülerek yara kültürlerinde üreyen mikroorganizmaların dağılımına bakıldı. Bu işlem sonucunda yara kültürlerinde üreyen mikroorganizmaların dağılımının değiştiği ve en sık üreyen mikroorganizmaların Staphylococcus türleri olduğu görüldü. Bunları sırasıyla Candida türleri $(\% 14,3 ; n=35)$, Pseudomonas aureginosa (\%14; $n=30$ )'ünde izledi. Kültür sayısı dikkate alınarak yapılan istatistikte en sık üreyen mikroorganizma olan Acinetobacter baumannii'nin, bu dağılımda kültürlerin \%13 ( $n=28)^{\prime}$ ünde üreyerek dördüncü sıraya kadar gerilediği görüldü.

Hastaların 139'unda toplam 524 kan kültürü çalışıldı. Kültür

Tablo 1. Kültür sayıları bazlı yara kültürlerinde üreyen mikro organizmaların dağılımı

\begin{tabular}{|l|l|c|c|c|c|}
\hline & Mikroorganizma & Tek üreme & Çoklu üreme* & $\begin{array}{l}\text { Toplam üreme } \\
(\mathrm{n}=346)\end{array}$ & $\%$ \\
\hline 1 & Acinetobacter baumannii & 68 & 22 & 90 & 25,9 \\
\hline 2 & Staphylococcus türleri & 55 & 12 & 67 & 19,3 \\
\hline 3 & Pseudomonas aureginosa & 50 & 17 & 67 & 19,3 \\
\hline 4 & Candidatürleri & 33 & 11 & 44 & 12,6 \\
\hline 5 & Klebsiella & 11 & 13 & 24 & 6,8 \\
\hline 6 & Escherichia coli & & 7 & 13 & 3,6 \\
\hline 7 & Streptococcus türleri & 4 & 6 & 10 & 2,9 \\
\hline 8 & Enterococcus & 6 & 3 & 9 & 2,6 \\
\hline 9 & Küf mantarı (Penicilium türleri) & 7 & 2 & 9 & 2,6 \\
\hline 10 & Enterobacter türleri türleri & 3 & 2 & 5 & 1,4 \\
\hline 11 & Serratia marcescens & 2 & 1 & 3 & 0,9 \\
\hline 12 & Corynebacterium striatum & 2 & 0 & 2 & 0,6 \\
\hline 13 & Aspergillus & 1 & 0 & 1 & 0,6 \\
\hline 14 & Providencia & 1 & 0 & 1 & 0,3 \\
\hline 15 & Proteus mirabilis & 1 & 1 & 2 & 0,3 \\
\hline 16 & Difteroid & 1 & 0 & 1 & 0,3 \\
\hline & Toplam & $251^{* *}$ & 97 & 348 & 100,0 \\
\hline & & & & \\
\hline
\end{tabular}

*Aynı yara kültüründe birden fazla mikroorganizmanın ürediği kültür sayısı 46 olup Tablo2'de detaylı olarak verilmiştir.

** Birden fazla mikroorganizmanın ürediği 46 kültür ile toplam 297 kültür 
Tablo 2. Kültür sayısı baz alındığında birden fazla mikroorganizmanın birlikte ürediği yara kültürleri

\begin{tabular}{|c|c|c|}
\hline & Mikroorganizma & Kültür sayısı \\
\hline 1 & Acinetobacter baumannii + Pseudomonas aureginosa & 12 \\
\hline 2 & Acinetobacter baumannii + Klebsiella & 4 \\
\hline 3 & Streptococcus + Candida türleri & 3 \\
\hline 4 & Acinetobacter baumannii+ Candida türleri & 3 \\
\hline 5 & Staphylococcus türleri + Klebsiella & 2 \\
\hline 6 & Staphylococcus türleri+ Escherichia coli & 2 \\
\hline 7 & Escherichia coli + Klebsiella & 1 \\
\hline 8 & Escherichia coli+Enterobacter türleri & 1 \\
\hline 9 & Staphylococcus türleri + Enterococcus & 1 \\
\hline 10 & Staphylococcus türleri + Candida türleri & 1 \\
\hline 11 & Pseudomonas aureginosa + Klebsiella+Streptococcus türleri & 1 \\
\hline 12 & Küf Mantarı+ Enterococcus & 1 \\
\hline 13 & Staphylococcus türleri + Streptococcus türleri & 1 \\
\hline 14 & Enterococcus + Escherichia coli & 1 \\
\hline 15 & Proteus + Staphylococcus türleri & 1 \\
\hline 16 & Enterobacter türleri + Klebsiella & 1 \\
\hline 17 & Klebsiella + Streptococcus türleri+ Candida türleri & 1 \\
\hline 18 & Klebsiella + Candida türleri & 1 \\
\hline 19 & Acinetobacter baumannii+ Serratia marcescens & 1 \\
\hline 20 & Küf Mantarı + Candida türleri & 1 \\
\hline 21 & Pseudomonas aureginosa + Klebsiella + Escherichia coli & 1 \\
\hline 22 & $\begin{array}{l}\text { Staphylococcus türleri + Acinetobacter baumannii + Klebsiella } \\
+ \text { Escherichia coli }\end{array}$ & 1 \\
\hline 23 & Staphylococcus türleri + Acinetobacter baumannii & 1 \\
\hline 24 & Pseudomonas aureginosa + Candida türleri & 1 \\
\hline 25 & Pseudomonas aureginosa + Staphylococcus türleri & 2 \\
\hline & Toplam & 46 \\
\hline
\end{tabular}

istenen hastaların \%31 ( $\mathrm{n=43)}$ 'inde üreme oldu. Bakılan toplam kan kültürü sayısı baz alındığında en çok üreyen mikroorganizma Staphylococcus türleri $(\% 29,7 ; n=30)$ idi (Tablo 3 ve Tablo 4). Bunu sırasıyla Candida türleri (\%20,8; $\mathrm{n}=21)$, Acinetobacter baumannii (\%12,8; $\mathrm{n}=13)$, Enterococcus $(\% 7,9 ; n=8)$, Pseudomonas aureginosa $(\% 6,9 ; n=7)$, Klebsiella $(\% 6,9 ; n=7)$ ve diğer bakteri türleri izledi. Yara kültürleri için yapılan işlem kan kültürleri için de yapıldı ve aynı hastada, aynı gün içinde alınan ve birden fazla üreyenlerin sayısı bire düşürülerek kan kültürlerinde üreyen mikroorganizmaların dağılımı yeniden ortaya konuldu. Bu işlem sonucunda kan kültürlerinde üreyen mikroorganizmaların dağılımında önemli bir değişiklik olmadığı ve Staphylococcus türleri'nin en sık ürediği görüldü. 503 hastanın \%21,5 (n=108)'inden idrar

Tablo 3. Kültür sayısı baz alındığında kan kültürlerinde üreyen mikroorganizmaların dağılımı

\begin{tabular}{|l|l|c|c|c|c|}
\hline & Mikroorganizma & Tek üreme & Çoklu üreme* & Toplam üreme $(\mathrm{n}=101)$ & $\%$ \\
\hline$(\mathrm{n})$ & & & $(\mathrm{n})$ & 30 & 29,7 \\
\hline 1 & Staphylococcus türleri & 28 & 2 & 21 & 20,8 \\
\hline 2 & Candida türleri & 18 & 3 & 13 & 12,8 \\
\hline 3 & Acinetobacter baumannii & 12 & 1 & 8 & 7,9 \\
\hline 4 & Enterococcus & 6 & 2 & 7 & 6,9 \\
\hline 5 & Pseudomonas aureginosa & 6 & 1 & 7 & 6,9 \\
\hline 6 & Klebsiella & 6 & 1 & 4 & 4,0 \\
\hline 7 & Streptococcus türleri & 3 & 1 & 4 & 4,0 \\
\hline 8 & Escherichia coli & 2 & 2 & 2 & 2,0 \\
\hline 9 & Enterobacter türleri & 2 & 0 & 2 & 2,0 \\
\hline 10 & Serratia marcescens & 1 & 1 & 1 & 1,0 \\
\hline 11 & Bacillus türleri & 1 & 0 & 1 & 1,0 \\
\hline 12 & Edwardsiella ictaluri & 1 & 0 & 1 & 1,0 \\
\hline 13 & Pantoea agglomerans & 1 & 0 & 101 & 100,0 \\
\hline & TOPLAM & $87^{* *}$ & 14 & & \\
\hline
\end{tabular}

*Aynı yara kültüründe birden çok mikroorganizmanın ürediği kültür sayısı 7 olup, Tablo 4'de detaylı olarak verilmiştir.

** Birden fazla mikroorganizmanın ürediği 7 kültür ile toplam 94 kültür 
Tablo 4. Birden fazla mikroorganizmanın birlikte ürediği kültür bazlı kan kültürleri

\begin{tabular}{|c|l|c|}
\hline & Mikroorganizma & Kültür sayısı \\
\hline 1 & Acinetobacter baumannii+ Serratia marcescens & 1 \\
\hline 2 & Escherichia coli + Klebsiella & 1 \\
\hline 3 & Staphylococcus türleri + Candida türleri & 1 \\
\hline 4 & Escherichia coli + Pseudomonas aureginosa & 1 \\
\hline 5 & Staphylococcus türleri + Streptococcus türleri & 1 \\
\hline 6 & Enterococcus + Candida türleri & 2 \\
\hline & Toplam & 7 \\
\hline
\end{tabular}

kültürü çalışıldı ve bunların \%14 ( $\mathrm{n=14}$ )'ünde üreme oldu. İdrar kültürlerinde en çok üreyen mikroorganizma Escherichia coli $(\% 33,3 ; n=6)$ idi. Klebsiella ise kültürlerin \%27,8 $(n=5)^{\prime}$ inde üreyerek ikinci sırada yer aldı.

25 hastadan toplam 42 kateter kültürü istendi. Bu kültürlerin 14'ünde üreme oldu. Kateter kültürlerinde en sık Candida türleri $(\% 35,7 ; n=5)$ üredi. Acinetobacter baumannii kültürlerin $\% 28,6 \quad(n=4)$ 'sında, Pseudomonas aureginosa ise $\% 7,1$ $(\mathrm{n}=1)^{\prime}$ 'inde üredi.

Hastalar yanık büyüklüklerine göre kültürde üreme, yatış süresi, greft ihtiyacı ve mortalite yönünden karşılaştırıldı. Hastaların yanık yüzdesi ile yatış süresi arasında istatistiksel olarak anlamlı ilişki olduğu görüldü ( $r h o=0,478 ; p<0,001$ ). Kültürlerinde üreme olan, kaybedilen ve greft yapılan hastaların yanık yüzdelerinin diğer hastalardan daha yüksek olduğu görüldü $(P<0,001)$. Kültürlerinde üreme olan hastaların yanık yüzdesi ortancası $30(C ̧ A G=20)$ bulunurken, üreme olmayan hastaların yanık yüzdesi ortancası 13 (ÇAG=10) $(\mathrm{Z}=10,442 ; \mathrm{P}<0,001)$ bulundu. Kaybedilen hastaların yanık yüzdesi ortancası 55 (ÇAG=30) bulunurken taburcu edilen hastalarda bu değer 15 (10) bulundu $(Z=5,469 ; P<0,001)$. Greft yapılan hastalarında yanık yüzdelerinin ortancası yapılmayanlara göre daha yüksekti. Greft yapılan hastaların yanık alanlarının yapılmayanlara göre daha büyük olduğu ve buna paralel olarak kültürlerinde üreme oranlarının cerrahi girişim (greft) yapılmayanlardan daha yüksek olduğu görüldü. Hastaların yanık yüzdeleri ile kültür üreme, greft yapılma oranı ve mortalite ile ilişkisi Tablo 5'de verilmiştir.

Tablo 5. Hastaların yanık yüzdeleri ile kültürde üreme, greft yapılma oranı ve mortalite ile ilişkisi

\begin{tabular}{|l|l|l|l|}
\hline & Yanık yüzdesi ortanca (ÇAG) & Z & P \\
\hline Kültürde üreme & & & \\
\hline Olmayan hastalar & $13(10)$ & 10,442 & $<0,001$ \\
\hline Olan hastalar & $30(20)$ & & \\
\hline Sonuç & & 5,469 & $<0,001$ \\
\hline Taburcu edilen hastalar & $15(10)$ & & \\
\hline Kaybedilen hastalar & $55(30)$ & & \\
\hline Greft & & 6,602 & $<0,001$ \\
\cline { 1 - 2 } Yapılmayan hastalar & $14(10)$ & & \\
\hline Yapılan hastalar & $20(22)$ & & \\
\hline
\end{tabular}

Hastaları yanık alanlarının büyüklüklerine göre üç gruba ayırdık. Yanık alanı vücut yüzey alanınının \%20'sinden küçük olanlar, yanık alanı vücut yüzey alanının \%20-39' u arasında olanlar ve yanık alanı vücut yüzey alanınının \%40'ından büyük olanlar.

Bu üçgruptakihastaların kültürlerinde üremeoranlarıaçısından gruplar arasında anlamlı farklılık saptandı ( $2=113,389 ; \mathrm{P}<$ $0,001)$. <\%20 yanıkları olan hastaların kültürlerinde $\% 8,2 ; \% 20$ -40 yanıkları olan hastaların kültürlerinde $\% 38,8$ ve $>\% 40$ yanıkları olan hastaların kültürlerinde ise $\% 67,8$ oranında üreme vardı. Hastaların yanık yüzey alanı büyüdükçe kültür pozitifliği artış gösterdi (Tablo 6). Ayrıca bu gruplardaki hastaların yatış süreleri açısından istatistiksel olarak anlamlı fark vardı ( 2 =71,974; $P<0,001)$. İkili karşılaştırma sonucunda; $\%$ 20-39 ve $>\% 40$ grupları arasında anlamlı fark olmadığı tespit edildi $(P=0,376)$. Yanık yüzey alanları $<\% 20$ olan hastaların yatış süresi <\%20-39 ve $>\% 40$ olan hastalardan daha düşüktü $(P<0,001)$. Kaybedilen 10 hastanın yanık yüzey alanı $>\% 40$ iken bir hastanın yanık yüzey alanı \%20-40 arasındaydı. Hastaların kültürde üreme, yatış süreleri ve mortalite açısından karşılaştırılması Tablo 6'da verilmiştir. 
Tablo 3. Kültür sayısı baz alındığında kan kültürlerinde üreyen mikroorganizmaların dağılımı

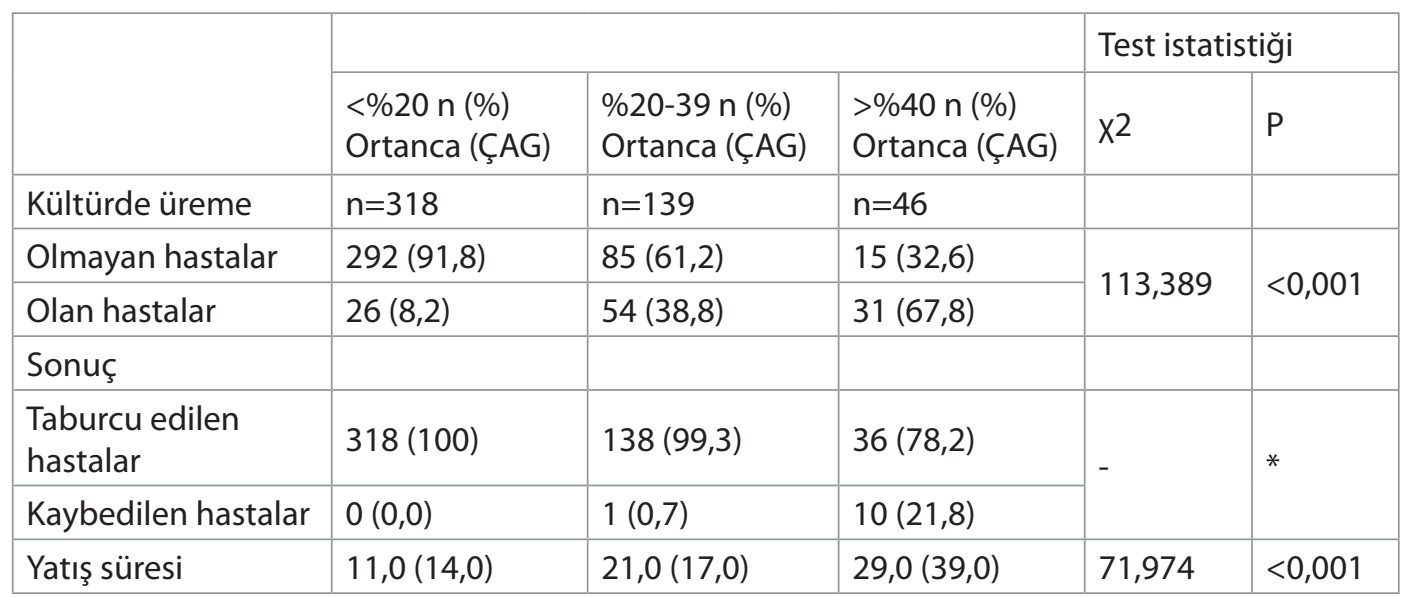

Yanık merkezimizde yatarak tedavi gören 503 hastadan 11'i gelişen çoklu organ yetmezliği nedeni ile 1'i ise sepsis ve eşlik olgu kaybedildi. Bu hastaların \%54,4 ( $=6$ )'ü enfeksiyonlar eden pnömoni nedeni ile kaybedildi. Kaybedilen hastaların nedeni ile kaybedildi. Beş hasta sepsis ve bunun sonucunda ölüm nedenleri Tablo 7'de verilmiştir.

Tablo 7. Kaybedilen hastaların ölüm nedenleri

\begin{tabular}{|l|l|l|}
\hline Ölüm Nedenleri & $\mathrm{n}$ & $\%$ \\
\hline Akut Solunum Yetmezliği & 4 & 36,4 \\
\hline $\begin{array}{l}\text { Sepsis + Çoklu Organ } \\
\text { Yetmezliği }\end{array}$ & 5 & 45,4 \\
\hline Aspirasyon & 1 & 9,1 \\
\hline Sepsis + Pnömoni & 1 & 9,1 \\
\hline Toplam & 11 & 100 \\
\hline
\end{tabular}

Enfeksiyonlar nedeni ile kaybedilen hastaların kültürlerinde üreyen mikroorganizmalar Tablo 8'de verilmiştir.

Tablo 8. Enfeksiyonlar nedeni ile kaybedilen hastaların kültür sonuçları

\begin{tabular}{|c|c|c|c|c|c|c|}
\hline No & Ölüm nedeni & Yara Kültürü & Kan Kültürü & Kateter Kültürü & İdrar & Diğer \\
\hline 1 & $\begin{array}{l}\text { Sepsis + } \\
\text { ÇOYS* }\end{array}$ & $\begin{array}{l}\text { Acinetobacter bau- } \\
\text { mannii } \\
\text { Streptococcus türleri, } \\
\text { Staphilococcus türleri }\end{array}$ & $\begin{array}{l}\text { Escherichia coli, } \\
\text { Klebsiella }\end{array}$ & İstenmedi & İstenmedi & İstenmedi \\
\hline 2 & Sepsis + ÇOYS & $\begin{array}{l}\text { Psödomonas auregi- } \\
\text { nosa }\end{array}$ & Üreme Olmadı & Üreme Olmadı & Üreme Olmadı & İstenmedi \\
\hline 3 & $\begin{array}{l}\text { Sepsis + Pnö- } \\
\text { moni }\end{array}$ & $\begin{array}{l}\text { Acinetobacter bau- } \\
\text { mannii }\end{array}$ & Üreme Olmadı & İstenmedi & İstenmedi & $\begin{array}{l}\text { Trakeal } \\
\text { Aspiratta } \\
\text { Acinetobacter } \\
\text { baumanni }\end{array}$ \\
\hline 4 & Sepsis + ÇOYS & Üreme Olmadı & Psödomonas aureginosa & Üreme Olmadı & Üreme Olmadı & İstenmedi \\
\hline 5 & Sepsis + ÇOYS & $\begin{array}{l}\text { Psödomonas auregi- } \\
\text { nosa, } \\
\text { Candida türleri Acine- } \\
\text { tobacter baumannii }\end{array}$ & $\begin{array}{l}\text { Psödomonas aureginosa, } \\
\text { Acinetobacter baumannii, } \\
\text { Candida türleri }\end{array}$ & Üreme Olmadı & Üreme Olmadı & İstenmedi \\
\hline 6 & Sepsis + ÇOYS & $\begin{array}{l}\text { Psödomonas auregi- } \\
\text { nosa } \\
\text { Acinetobacter bau- } \\
\text { mannii } \\
\text { Streptococcus türleri } \\
\text { Staphilococcus türleri } \\
\text { Escherichia coli } \\
\text { Candida türleri }\end{array}$ & $\begin{array}{l}\text { Psödomonas aureginosa } \\
\text { Acinetobacter baumannii } \\
\text { Candida türleri Enterococcus } \\
\text { Edwardsiella ictaluri } \\
\text { Pantoea agglomerans } \\
\text { Streptococcus türleri Staph- } \\
\text { ylococcus türleri }\end{array}$ & $\begin{array}{l}\text { Acinetobacter } \\
\text { baumannii } \\
\text { Streptococcus } \\
\text { türleri } \\
\text { Candida türleri } \\
\text { Enterococcus }\end{array}$ & Üreme Olmadı & İstenmedi \\
\hline
\end{tabular}




\section{Tartışma}

Yanık hastaları yüksek morbidite ve mortaliteye sahip kritik hasta grubunu oluştururlar. Çocuk yanık hastalarında enfeksiyonlar, mortalite ve morbiditenin en sık nedeni olmaya devam etmektedir [4]. Bu nedenle enfeksiyonların kontrol altına alınması ve yaralarını erken kapatılması ile büyük yanıklı çocuk hastalarda daha iyi sonuçlar alınması beklenmektedir [5]. Nozokomiyal enfeksiyonlar yanık hastalarında, cerrahi işlem yapılan diğer hastalardan daha fazla görülür [6].

Hastaların yara kültürlerinde kültür sayıları baz alındığında en sık üreyen mikroorganizmanın Acinetobacter baumannii olduğu (\%25,9; n=90) görüldü. Staphyolococcus türleri ve Psödomonas aureginosa yara kültürlerinin \%19,3 (n=67)'unda üreyerek ikinci ve üçüncü en sık üreyen mikroorganizmalar oldular. Yara kültür sayıları baz alınarak yapılan istatistikte yanılmalar olabileceği düşünülerek hasta bazlı olarak tekrar değerlendirildiğinde yara kültürlerinde üreyen mikroorganizmaların dağılımının değiştiği görüldü. Hastalar baz alınarak yapılan yeni dağılımda yara kültürlerinde en sık Staphyolococcus türlerinin $(\% 25,6 ; n=55)$ ürediği görüldü. Literatürde her iki şekilde de veriler paylaşılmasına rağmen, hasta bazlı değerlendirmenin daha doğru olduğu kanaatindeyiz.

Geçen yüzyılın başlarında yanık yara sepsislerinin en sık nedeni Streptococcus pyogenes iken yıllar geçtikçe Staphyolococcus aureus ve Pseudomonas aeruginosa yanık ünitelerinde yara kültürlerinden en sık izole edilen mikroorganizmalar haline gelmişlerdir [2]. Günümüzde ise yanık hastalarının yara kültürlerinde üreyen mikroorganizmaların dağılımı merkezden merkeze değişkenlik göstermekle birlikte en sık üreyen mikroorganizmalar; Staphyolococcus türleri, Pseudomonas aureginosa, Acinetobacter türleri, Enterobakterler, Klebsiella türleri, Streptococcus türleri ve Candida türleridirler. Ülkemizde yapılan bazı çalışmalarda yara kültürlerinde en sık üreyen mikroorganizmanın Pseudomonas aureginosa olduğu bildirilirken [7-9], daha sıklıkla Staphyolococcus türleri olduğu bildirilmiştir [10-12]. Yurtdışından yapılan bir çalışmada en sık üreyen mikroorganizma olarak Klebsiella [13], başka bir çalışmada Pseudomonas aureginosa [14] bildirilmiş olmakla birlikte, çalışmaların büyük bir kısmında en sık üreyen mikroorganizmanın Staphyolococcus türleri olduğu bildirilmiştir [10,15-18]. Bu sonuçlar, özellikle Avrupa'da Staphylococcus aureus başta olmak üzere Staphylococcus türlerinin halen yanık yara kültürlerinde en sık izole edilen mikroorganizmalar olduğunu göstermektedir. Hastalarımızın yara kültür sonuçları özellikle Avrupa'daki yanık merkezlerinin sonuçları ile uyumludur.

Hastaların kan kültürlerinde en sık üreyen mikroorganizmanın Staphyolococcus türleri \%29,7; n=30) olduğu görüldü. Bunu sırasıyla Candida türleri $(\% 20,8)$, Acinetobacter baumannii $(\% 12,8)$ ve diğer mikroorganizmaların (\%7) izledi.

Staphylococcus aureus, çoğu yanık merkezinde sepsis atağı geçiren hastaların kan kültürlerinde de en sık izole edilen mikroorganizmadır [11]. Appelgren ve ark. kan kültürlerinde en sık üreyen mikroorganizma olarak Staphylococcus türlerini bildirmiştir [10]. Weber ve ark. da çalışmalarında kan kültürlerinde en sık Staphylococcos türlerinin $(\% 29,1)$, bunu takiben Pseudomonas aureginosa $(\% 13,9)$, Enterobacter türleri $(\% 8,8)$, Candida türleri $(\% 8,8)$, Enterococcus türleri $(\% 7,3)$, Escherichia coli $(\% 7,3)$ ve diğer mikroorganizmaların $(\% 24,8)$ ürediğini bildirmiştir [6].

Ülkemizden yapılan iki çalışmada kan kültürlerinde en sık üreyen mikroorganizma olarak Staphylococcus türleri bildirilirken, bunu sıklık sırasına göre Pseudomonas aureginosa, Acinetobacter türleri, Enterococcus, Proteus türleri ve diğer mikroorganizmaların izlediği belirtilmiştir $[19,9]$. Ülkemizden yapılan farklı iki çalışmada ise kan kültürlerinde en sık üreyen mikroorganizma olarak Pseudomonas aeruginosa bildirilmiştir [20,21].

$\mathrm{Bu}$ sonuçlar, Staphylococcus aureus başta olmak üzere Staphylococcus türlerinin halen yanık yara kültürlerinde olduğu gibi yanık merkezlerinde yatan hastaların kan kültürlerinde de en sık izole edilen mikroorganizmalar olduğunu göstermektedir. Candida türleri ve Acinetobacter türlerinin son zamanlarda yanık merkezlerinde daha fazla izole edildiği bilinmektedir [22-24]. Bizim hastalarımızda da bu iki mikroorganizma Staphylococcus türlerinden sonra en sık izole edilen mikroorganizmalar olmuşlardır. Bununla birlikte bizim çalışmamızda kan kültürlerinde Candida türlerinin literatüre göre daha yüksek oranda ürediği görülmüştür. Merkezimize periferden kabul edilen hastalarda, kabul sırasında alınan kültürlerde ciddi enfeksiyon etkenlerinin üremesi nedeni ile genellikle geniş spektrumlu antibiyotik tedavisine başlanmak zorunda kalınmıştır. Bu zorunluluğun kaçınılmaz olarak mantar enfeksiyonlarının sıklığını arttırdığı düşünüldü.

İdrar yolları enfeksiyonları, özellikle perine yanıkları olan hastalarında ve / veya idrar çıkışı miktarını takip etmek için mesanelerine foley kateter yerleştirilen yanık hastalarında daha sık görülür. Bu nedenle foley kateterleri en kısa zamanda çıkarılmasının önemli olduğu vurgulanmıştır [12]. Bizim çalışmamızda, hastalarımızın idrar kültürlerinde en sık üreyen mikroorganizma Escherichia coli olarak tespit edildi. Escherichia coli idrar kültürlerinin \%33,3'ünde ürerken, Klebsiella \%27,8'inde, Candida suşları ise \%22,2'inde üredi.

Hastalarımızın santral venöz kateter (CVC) kültürlerinde en sık Candida türleri $(\% 35,7)$ ürerken, bunu Acinetobacter baumannii $(\% 28,6)$ ve Psödomonas aureginosa $(\% 7,1)$ takip etmiştir. Rodgers ve ark. çalışmasında çocuk yanık hastalarının CVC kateterlerinde en sık Staphylococcus türleri $(n=11)^{\prime} n i n$, bunu takiben sırasıyla Enterococcus türleri $(n=2)$, Pseudomonas aeruginosa $(n=1)$, Candida albicans $(n=1)$ ve Klebsiella oxytoca $(n=1)$ ürediği belirtmişlerdir [13]. Literatürde özellikle çocuk yanık hastalarında CVC ile ilgili yeterince yayın yoktur. Bizim verilerimiz bu konuda literatüre katkı sağlayacaktır.

Sevkli gelen hastalardan ilk başvurulan sağlık kuruluşunda yatırılmadan sevk edilen 307'sinin \%23,8 (n=73)'inde kültürde üreme oldu. İlk başvurulan sağlık kuruluşunda yatırılan 87 hastanın \%39,9 (n=34)'unda üreme oldu. İlk başvurulan sağlık kuruluşunda yatırılıp sonra sevk edilen hastaların kültürlerinde 
daha fazla üreme olduğu görüldü $(x 2=17,595 ; P<0,001)$. Ilk başvurulan sağlık kuruluşunda uzun süre yatırılıp kliniğimize sevk edilen hastalarda özellikle Acinetobacter baumannii ve Pseudomonas aureginosa sık izole edildi.

Kaybettiğimiz 11 hastanın ölüm nedenleri olarak 6 olguda $(\% 54,5)$ enfeksiyonlar, 4 olguda $(\% 36,7)$ akut solunum yetmezliği, 1 olguda ise $(\% 9,1)$ aspirasyon belirlendi. Rosanova kaybedilen hastaların \%82'sinin enfeksiyonlar ve buna bağlı komplikasyonlar nedeni ile kaybedildiğini bildirmiştir [7]. Literatürde çocuk yanıklarında en sık ölüm nedeni olarak enfeksiyonlar ve buna bağlı komplikasyonlar bildirilmiştir. Bizim verilerimizde literatür ile uyumludur [5,19,11, 25-27].

Bulgularda belirtilen enfeksiyonlar nedeni ile kaybedilen hastaların kültürlerinde üreyen mikroorganizmalar yanık ve yoğun bakım ünitelerinde en sık mortalite nedenleri olarak bildirilen mikroorganizmalardır. Üreme sonuçları literatür ile uyumludur [24, 28-34].

Yanık merkezimizin enfeksiyonlara yaklaşımı ve antibimikrobiyal tedavi politikası yatırılan hastalara gereksiz antibiyotik kullanımından kaçınılmaktadır. Yanık yaraları temiz, klinik olarak enfeksiyon bulguları ve kültürlerinde üreme olmayan, cerrahi girişim yapılması düşünülmeyen hastalara antibiyotik başlanmamaktadır. Enfeksiyon bulguları başladığında kültürleri bakılmakta ve kültür sonuçlarına göre gerekirse antibiyotik başlanmaktadır. İstisna olarak elektrik yanıkları, inhalasyon hasarı, başka bir travma ile birlikte yanık yarasının olması, yanık alanlarının >\%40 olması, yanık alanlarının derin ve kirli olması, yanık dışında antibiyotik kullanımını gerektiren bir enfeksiyon odağının olması durumunda, geniş spektrumlu antibiyotik tedavisi başlanmaktadır. Ayrıca, kültürde üreme olmasa da klinik olarak sepsis bulguları varsa, enfeksiyon hastalıkları uzmanının da önerisi ile ampirik antibiyotik tedavisi başlanmaktadır.

Yanık merkezimize yatırılıp tedavileri yapılan 503 hastada mortalite oranımız \%2,2 ( $n=11)$ bulundu. Olguların 6'sında ölüm nedeni enfeksiyonlar, 4 olguda akut solunum yetmezliği ve 1olguda aspirasyon olarak belirlendi. Kaybedilen hastaların 5 'inde yanık etkeni sıcak sıvılar, $5^{\prime}$ inde alev yanığı ve $1^{\prime}$ inde ise elektrik yanığı olarak belirlendi. Kaybedilen hastaların tamamı dışarıdan sevkli gelen hastalardı.

Sonuç olarak yanık hastalarında enfeksiyon hala önemli mortalite nedenidirler. Doku bütünlüğü bozulmuş, immün sistemi baskılanmış, beslenmesi etkilenmiş bu hastalarda sepsis en önemli mortalite nedenlerinden biri olmaya devam etmektedir. Buna neden olan mikroorganizmalar olarak Pseudomonasa eroginosa, Acinetobacter baumannii, Staphylococcus türleri ve Candida türleri öne çıkmaktadır.

\section{Çıkar çatışması ve Finansman Beyanı}

Bu çalışmada çıkar çatışması ve finansman destek alındığı beyan edilmemiş̧ir.

\section{Kaynaklar}

1. Barret-Nerín JP, Herndon DN. Initial Management and Resuscitation. Principles and practice of burn surgery. 1.st ed. New York: Marcel Dekker; p. 1-23.

2. Sharma B.R. Infection in patients with severe burns: causes and prevention thereof. Infect Dis Clin N Am 2007; 21: 745-759.

3. Oral Öncül. Yanık enfeksiyonları. İ.Ü. Cerrahpaşa Tıp Fakültesi Sürekli Tıp Eğitimi Etkinlikleri. Hastane Enfeksiyonları: Korunma Ve Kontrol. Sempozyum Dizisi No:60 Ocak 2008; S.105-119.

4. Peck MD, Heimbach DM: Does early excision of burn wounds change the pattern of mortality?. J Burn Care Rehabil 1989; 10: 7-10.

5. Robert L. Sheridan. Sepsis in pediatric burn patients. Pediatr Crit Care Med 2005 Vol. 6, No. 3 (Suppl.). DOI: 10.1097/01. PCC.0000161577.27849.

6. Weber JM, Sheridan RL, Pasternack MS, Tompkins RG. Nosocomial infections in pediatric patients with burns. Am J Infect Control 1997; 25: 195-201.

7. Rosanova MT, Stamboulian D, Lede R. Infections in burned children: epidemiological and risk factor analysis. Arch Argent Pediatr 2013; 111; 303-8.

8. Ekiz F. Inhalation injury. Türkiye Klinikleri J Surg Med Sci 2007; 3: 73-5.

9. Senel E, Yasti AC, Reis E, Doganay M, Karacan CD, Kama NA. Effects on mortality of changing trends in the management of burned children in Turkey: Eight years' experience. Burns 2009; 35: 372-7

10. Aygıt AC, Pilancı Ö, Mercan EŞ. Evaluation of burn wound infection among patients in the age range of $0-12$ years in a burn unit. JAREM. 2012; 2: 55-8.

11. Tekin R, Yolbaş İ, Selçuk CT, Güneş A, Özhasanekler A, Aldemir M. An evaluation of pediatric burn patients over a 15 year period. Turk J Trau Emerg Surg 2012; 18: 514-8.

12. Bayram Y, Parlak M, Aypak C, Bayram I. Three-year Review of Bacteriological Profile and Antibiogram of Burn Wound Isolates in Van, Turkey. International Journal of Medical Sciences. 2013; 10(1):19-23. doi: 10.7150/ijms.4723

13. Srinivasan S, Vartak AM, Patil A, Saldanha J. Bacteriology of the burn wound at the Bai Jerbai Wadia Hospital for children, Mumbai, India-A 13-year study, Part I-Bacteriological profile. Indian J Plast Surg 2009; 42: 213-8.

14. Agnihotri N, Gupta V, Joshi RM. Aerobic bacterial isolates from burn wound infections and their antibiograms, a five-year study. Burns 2004; 30: 241-3. doi: 10.1016/j.burns.2003.11.010.

15. Qader AR, Muhamad JA. Nosocomial infection in Sulaimani burn hospital, Iraq. Annals of Burns and Fire Disasters 2010; 23: 177-181. 
16. Gastmeier P, Weigt $O$, Rüden H. Comparison of hospital-acquired infection rates in pediatric burn patients. Journal of hospital infection 2002; 52: 161-5.

17. de Macedo JL, Santos JB. Bacterial and fungal colonization of burn wounds. Mem Inst Oswaldo Cruz 2005; 100: 535-539.

18. Guggenheim $M$, Zbinden $R$, Handschin $A E$, et al. Changes in bacterial isolates from burn wounds and their antibiograms:A 20-year study (1986-2005). Burns 2009; 35: 553-60.

19. Yastı AÇ, Kabalak AA. Yanık hastalarda enfeksiyon etkenleri ve mortaliteye etkileri. Yoğun Bakım Derg 2012; 1: 1-4.

20. Barlas N, Savaf L, Yıldııım S. Yanık ünitesindeki hastalardan izole edilen bakterilerin dağılımı ve Pseudomonas aeruginosa türlerinın antibiyotiklere duyarlılıkları. X. Klinik Mikrobiyoloji ve İnfeksiyon Hastalıkları Kongresi (15-19 Ekim 2001, Adana) Program'da. İstanbul: KLiMiK Derneği, 2001: 304.

21. Çiftçi A, Aksaray S, Cesur S. Yanık ünitesinde yatan hastaların yara ve kan kültürlerinden izole edilen mikroorganizmalar ve antibiyotik duyarlılıkları. İnfeks Der 2003; 17: 293-6.

22. Chung DH, Herndon DN. Burns. In Aschcraft's Pediatric Surgery. Holcomb GW, Murphy P (Editors), Saunders-Elsevier, Philadelphia. 2012. P 154-164.

23. Martin GS, Mannino DM, Eaton S, et al. The epidemiology of sepsis in the United States from 1979 through 2000. N Engl J Med 2003; 348: 1546-54.

24. Ludwik K. Branski, Ahmed Al-Mousawi, Haidy Rivero, Marc G. Jeschke, Arthur P. Sanford, and David N. Herndon. Emerging Infections in Burns. Surgıcal Infectıons. Volume 10, Number 5, 2009. 389-397. DOI: $10.1089=$ sur.2009.024.
25. Sakallıoğlu AE, Başaran Ö, Tarım A, Türk E, Kut A, Haberal M. Burns in Turkish children and adolescents: Nine years of experience. Burns 2007; 33: 46-51.

26. de Macedo JL, Rosa SC, Castro C. Sepsis in burned patients. Rev Soc Bras Med Trop 2003; 36: 647-52.

27. Bang RL, Sharma PN, Sanyal SC, Sarla Bang S, Ebrahim MK. Burn Septicaemia in Kuwait: Associated Demographic and Clinical Factors. Med Princ Pract 2004; 13: 136-41.

28. Oral ÖNCÜL. Yanık İnfeksiyonları. Turkiye Klinikleri J Surg Med Sci 2007; 3: 41-5.

29. Dean DA, Burchard KW. Fungal infection in surgical patients. Am J Surg 1996; 171: 374-82.

30. Gang RK, Bang RL, Sanyal SC, Mokaddas E, Lari AR. Pseudomonas aeruginosa septicaemia in burns. Burns 1999; 25: 611-6.

31. Kolmos HJ, Thuesen B, Nielsen SV, Lohmann M, Kristoffersen $\mathrm{K}$, Rosdahl VT. Outbreak of infection in a burn unit due to Pseudomonas aeruginosaoriginating from contaminated tubing used for irrigation of patients. J Hosp Infect 1993; 24: 11-21.

32. Richard P, Le Floch R, Catherine C, Pannier M, Espaze E, Richet $H$. Pseudomonas aeruginosaoutbreak in a burn unit: role of antimicrobials in the emergence of multiple resistant strains. J Infect Dis 1994; 170: 377-83.

33. Geyik MF, Aldemir M, Hosoglu S, Tacyildiz HI. Epidemiology of burn unit infections in children. Am J Infect Control 2003; 31: 342-6.

34. Leseva M, Arguirova M, Nashev D, Zamfirova E, Hadzhyiski O. Nosocomial infections in burn patients: Etiology, antimicrobial resistance, means to control. Annals of Burns and Fire Disasters Vol. XXVI - n. 1 - March 2013. 